\title{
PENGARUH GENOTIP CEKAMAN KEKERINGAN DAN TINGKAT NETRALISASI ALUMINIUM TERHADAP KOMPONEN HASIL KEDELAI
}

\author{
${ }^{1}$ Elfi Yenyy Yusuf \\ ${ }^{1}$ Jurusan Agroteknologi, Fakultas Pertanian, Universitas Islam Indragiri \\ Email: elfiyenny eltra@yahoo.com
}

\begin{abstract}
Cultivation of crops on acid dry land faces several obstacles, including drought and high Al3 + solubility. The response of soybean to water deficit varies depending on the plant species, the size and duration of stress and the growth phase. The high solubility of Al3 + in the soil is toxic to plants, thus inhibiting root function and growth. The purpose of this study was to study the growth response and tolerance mechanisms of soybeans under drought and aluminum stress conditions. This study used a completely randomized design (CRD) 3 factors with 3 replications, consisting of soybean genotypes (SP 30-4, PG 57-1, Anjasmoro and Tanggamus), drought periods (2, 6 and 10 days), and Al neutralization ( $0 \times$ Aldd and $1 \times$ Aldd). The differences in growth response between genotypes to Al stress and drought were seen in the variables of plant height, root length, nodule dry weight, flowering age and water use efficiency. The PG 57-1 line showed a tolerance mechanism for the root length variable. When stressed by Al, the higher water use efficiency values were shown by the PG 57-1 line and Anjasmoro variety.
\end{abstract}

Keywords: drought stress, aluminum stress, tolerance mechanism

\begin{abstract}
Abstrak
Budidaya tanaman di lahan kering masam menghadapi beberapa kendala diantaranya kekeringan dan kelarutan $\mathrm{Al}^{3+}$ yang tinggi. Respon tanaman kedelai terhadap defisit air berbeda-beda tergantung pada spesies tanaman, besar dan lamanya cekaman serta fase pertumbuhan. Kelarutan $\mathrm{Al}^{3+}$ yang tinggi dalam tanah bersifat racun bagi tanaman sehingga menghambat fungsi dan pertumbuhan akar. Tujuan penelitian ini untuk memperoleh informasi tentang komponen hasil kedelai pada kondisi tercekam Al dan kekeringan Penelitian ini menggunakan Rancangan Acak Lengkap (RAL) 3 faktor dengan 3 ulangan, terdiri atas genotipe kedelai (SP 30-4, PG 57-1, Anjasmoro dan Tanggamus), periode kekeringan (2,6 dan 10 hari), dan netralisasi Al ( 0 x Aldd dan 1 x Aldd). Perbedaan respon pertumbuhan antar genotipe terhadap cekaman Al dan kekeringan terlihat pada peubah, panjang akar, bobot kering bintil akar, dan jumlah daun
\end{abstract}

Kata kunci: cekaman kekeringan, cekaman aluminium, mekanisme toleransi

\section{PENDAHUlUAN}

Pemerintah telah mencanangkan swasembada kedelai pada tahun 2014. Hal tersebut akan tercapai dengan peningkatan produktivitas, perluasan intensitas tanam dan perluasan areal tanam. Pengembangan budidaya kedelai pada lahan-lahan marjinal seperti lahan kering masam merupakan salah satu usaha untuk meningkatkan produksi kedelai nasional. Namun usaha perluasan pertanaman di lahan kering masam menghadapi beberapa kendala yang merupakan faktor pembatas ekologi yaitu $\mathrm{pH}$ tanah yang rendah ( $\mathrm{pH} 4.0-5.0)$, kandungan hara dan bahan organik rendah, keterbatasan sumber air dan kelarutan $\mathrm{Al}^{3+}$ yang tinggi.

Kelarutan $\mathrm{Al}^{3+}$ yang tinggi dalam tanah bersifat racun bagi tanaman sehingga menghambat fungsi dan pertumbuhan akar (Kochian et al. 2005). Hal ini akan 
mempengaruhi perkembangan morfologi maupun proses fisiologi tanaman kedelai sehingga menyebabkan produksinya rendah. Gejala keracunan aluminium tidak mudah diidentifikasi. Pada beberapa tanaman gejala keracunan Al mirip dengan defisiensi fosfor, yaitu pertumbuhan terhambat, tanaman kerdil, urat-urat daun dan batang menjadi ungu, serta ujung daun menguning dan mati. Namun keracunan Al pada tanaman juga bisa mirip dengan defisiensi $\mathrm{Ca}$, yaitu keriput atau menggulungnya daun muda.

Gejala keracunan Al yang paling mudah dilihat adalah penghambatan pertumbuhan akar. Kandungan Al yang tinggi dapat mengganggu pertumbuhan kedelai dan merusak perakaran sehingga mengganggu penyerapan hara (Hanum et al. 2007). Hal ini disebabkan karena penghambatan pertumbuhan ujung akar (root apex) tanaman yang terdiri atas tudung dan meristem, sehingga mengakibatkan tidak efisiennya akar menyerap unsur hara dan air ( $\mathrm{Ma}$ et al. 2000). Tanggap morfologi akar tanaman terhadap keracunan Al berbeda antara tanaman toleran dan tanaman peka. Pada tanaman yang peka akan mengalami pemendekan akar karena keracunan Al (Rangeli et al. 2007) sehingga parameter panjang akar biasanya digunakan untuk menilai ketenggangan tanaman terhadap keracunan Al (Bakhtiar et al. 2007).

Keterbatasan suplai air dapat mempengaruhi fisiologi, biokimia, dan morfologi tanaman sehingga akan menyebabkan penurunan kualitas dan kuantitas produksi. Respon tanaman terhadap defisit air berbeda-beda tergantung pada spesies tanaman, besar dan lamanya cekaman serta fase pertumbuhan. Peningkatan cekaman air sampai $40 \%$ dari kadar air kapasitas lapang menyebabkan penurunan tinggi tanaman, bobot biji 100 butir dan indeks panen pada tanaman padi (Zubaer et al.2007). Semakin berat cekaman kekeringan, semakin tertekan pertumbuhan dan hasil kedelai yang ditunjukkan oleh penurunan bobot kering tajuk, diameter batang, jumlah cabang produktif, jumlah polong berisi, jumlah biji per tanaman dan bobot kering biji (Hapsoh et al. 2004). Pada fase generatif, kekeringan menyebabkan penurunan hasil kedelai karena jumlah biji per polong yang menurun akibat terjadinya gugur bunga dan polong pada saat fase pembungaan dan pembesaran polong (Liu et al. 2003), sedangkan kekeringan pada fase akhir pengisian polong akan mengurangi kepadatan biji (Liu et al. 2004). Totok dan Rahayu (2004) juga menambahkan bahwa karakter morfologi yang berhubungan dengan kekeringan adalah jumlah polong isi, bobot polong dan tinggi tanaman kedelai.

Tanaman yang toleran memiliki kemampuan memulihkan dan menekan pengaruh buruk keracunan Al sehingga fungsi akar tidak terganggu. Akar yang panjang dapat meningkatkan pengambilan hara dan air sehingga tanaman lebih adaptif pada kondisi cekaman Al dan kekeringan. Kemampuan akar untuk mengabsorbsi air sangat tergantung pada struktur morfologinya, akar yang panjang akan memiliki bidang serap yang lebih tinggi (Cruz et al. 1992). Menurut Taiz dan Zeiger (2002) salah satu pertahanan tanaman dalam menghadapi kekeringan adalah perkembangan akar untuk mencapai daerah yang masih basah. Informasi ini menunjukkan bahwa analisis pertumbuhan akar melalui studi perkembangan akar menjadi penting, disamping dapat menentukan daya toleransi terhadap cekaman Al juga dapat menduga kemampuan perakaran dalam keadaan keterbatasan air tanah.

\subsection{Tujuan}

1. Memperoleh informasi tentang komponen hasilkedelai pada kondisi tercekam Al dan kekeringan

\subsection{Hipotesis}

1. Terdapat pengaruh genotipe, cekaman aluminium dan cekaman kekeringan terhadap komponen hasil kedelai

\section{TINJAUAN PUSTAKA}

Botani Tanaman Kedelai Menurut Adisarwanto (2008), berdasarkan taksonomi tanaman kedelai dapat diklasifikasikan sebagai berikut: Divisi Spermathophyta, Subdivisi Angiospermae, Klas Dicotyledoneae, Subklas Archihlamydae, Ordo Rosales, Subordo Leguminoseae, Famili Leguminosae, Subfamili Papiolionaceae, fabaceae, Genus Glycine, Spesies Glycine max (L.) Merril. Di Indonesia pada zaman Rhumphius (abad ke 17), saat itu kedelai 
dibudidayakan sebagai tanaman makanan dan pupuk hijau. Sampai saat ini di Indonesia kedelai banyak ditanam di dataran rendah yang tidak mengandung air, misalnya di Pesisir Utara Jawa Timur, Jawa Tengah, Jawa Barat, Gorontalo (Sulawaesi Utara), Sulawesi Utara, Lampung, dan Sumatera Selatan serta Bali. Menurut para ahli tanaman kedelai yang sudah disebarluaskan di Indonesia bukanlah tanaman asli, melainkan tanaman yang berasal dari daerah Manshukuo di China, kemudian menyebar ke daerah Mansyuria dan Jepang (Asia Timur). Demikian pula kedelai yang ditanam di benua lain seperti Amerika dan Afrika pun berasal dari Asia (AAK, 2000).

Tanaman kedelai mempunyai banyak varietas unggul seperti: Pangrango, Kawi, Leuser, Sinabung, Bromo, Argomulyo, Anjasmoro, Maheru, Gumitir, Argopuro, Grobogan, Meratus, Metani dan masih banyak lagi jenis varietasnya (Adisarwanto, 2014).

Perakaran tanaman kedelai terdiri atas akar tunggang yang terbentuk dari bakal akar, empat baris akar sekunder yang tumbuh dari akar tunggang dan sejumlah cabang yang tumbuh dari akar sekunder, akar adventif tumbuh dari bagian bawah hipokotil (Suprapto, 1999). Sistem perakaran tanaman kedelai adalah adanya interaksi simbiosis antara bakteri nodul akar (Rhizobium japonikum) dengan akar tanaman kedelai yang menyebabkan terbentuknya bintil akar. Bintil akar ini sangat berperan dalam proses fiksasi N2 yang sangat dibutuhkan oleh tanaman kedelai untuk melanjutkan pertumbuhannya khususnya dalam penyediaan unsur hara nitrogen (Adisarwanto, 2014).

Tanaman kedelai dikenal dua tipe pertumbuhan batang, yaitu determinit dan interdeminit. Ciri determinit apabila pada akhir fase generatif pada pucuk batang tanaman ditumbuhi polong, sedangkan tipe interdeminit pada pucuk batang tanaman masih terdapat daun yang tumbuh. Jumlah buku pada batang akan bertambah sesuai pertambahan umur tanaman, tetapi pada kondisi normal jumlah buku berkisar $15-20$ buku dengan jarak antar buku berkisar 2 - 9 $\mathrm{cm}$. Batangkedelai ada yang becabang dan ada pula yang tidak bercabang, bergantung dari karakteristik varietas, akan tetapi umumnya cabang tanaman kedelai berjumlah antar 1 - 5 cabang (Adisarwanto, 2014)

Daun kedelai merupakan daun majemuk yang terdiri atas tiga helai anak daun dan umumnya berwarna hijau muda atau hijau kuning - kekuningan. Bentuk daun ada yang oval, juga ada yang segi tiga. Warna dan bentuk daun, bergantung pada varietas masing - masing. Pada saat tanaman kedelai itu sudah tua, maka daundaunnya mulai rontok (AAK, 2000).

Di Indonesia, kedelai berdaun sempit lebih banyak ditanam petani dibanding tanaman kedelai berdaun lebar, padahal dari aspek penyinaran matahari, tanaman kedelai berdaun lebar menyerap sinar matahari lebih banyak dari pada yang berdaun sempit. Namun, keunggulan tanaman kedelai berdaun sempit adalah sinar matahari akan mudah menerobos di antara kanopi daun, sehingga memacu pembentukan bunga (Adisarwanto, 2014).

Bunga pada tanaman kedelai umumnya muncul atau tumbuh pada ketiak daun, yakni setelah buku kedua, tetapi terkadang bunga dapat pula terbentuk pada cabang tanaman yang mempunyai daun. Hal ini karena sifat morfologi cabang tanaman kedelai serupa atau sama dengan morfologi batang utama. Pada kondisi lingkungan tumbuh dan populasi tanaman optimal, bunga akan terbentuk mulai dari tangkai daun yang paling bawah. Satu kelompok bunga, pada ketiak daunnya

akan berisi 1 - 7 bunga, bergantung dari karakter dari varietas kedelai yang ditanam. Bunga kedelai termasuk sempurna karena pada setiap bunga memiliki alat reproduksi jantan dan betina. Penyerbukan bunga terjadi pada saat bunga masih tertutup sehingga kemungkinan penyerbukan silang sangat kecil, yaitu hanya $0,1 \%$ warna bunga kedelai ada yang ungu dan putih. Potensi jumlah bunga yang terbentuk bervariasi, bergantung dari varietas kedelai, tetepi umumnya berkisar antara 40 - 200 bunga pertanaman. Masa pertumbuhan tanaman kedelai sering mengalami kerontokan bunga. Hal ini masih dikatagorikan wajar bila kerontokan yang terjadi pada kisaran 20 - 40\% (Adisarwanto, 2014)

Polong kedelai pertama kali muncul sekitar 10 - 14 hari setelah bunga pertama terbentuk. Warna polong yang baru tumbuh berwarna hijau dan selanjutnya akan berubah-ubah menjadi kuning atau kecoklatan pada saat panen. Pembentukan dan pembesaran polong akan meningkat sejalan dengan bertambahnya umur dan jumlah bunga yang terbentuk. Jumlah polong yang terbentuk beragam, yakni 2 10 polong pada setiap kelompok bunga diketiak daunnya. Sementara itu, jumlah 
polong yang dapat dipanen berkisar 20 200 polong atau tanaman bergantung pada varietas kedelai yang ditanam dan dukungan kondisi lingkungan tumbuh. Warna polong masak dan ukuran biji antara posisi polong paling bawah dengan paling atas akan sama selama periode pengisian dan pemasakan polong optimal, yaitu antara 50 - 75 hari. Periode waktu tersebut diangggap optimal untuk proses pengisian biji dalam polong yang terletak di sekitar pucuk tanaman (Adisarwanto, 2014).

Bentuk biji kedelai tidak sama tergantung varietas, ada yang berbentuk bulat, agak gepeng, atau bulat telur. Namun, sebagian besar biji kedelai berbentuk bulat telur. Ukuran dan warna biji kedelai juga tidak sama. Sebagian besar berwarna kuning dan sedikit berwarna hitam dengan ukuran biji kedelai yang dapat digolongkan dalam tiga kelompok, yaitu berbiji kecil

Tanaman kedelai sebagian besar tumbuh di daerah yang beriklim tropis dan subtropis. Sebagai barometer iklim yang cocok bagi kedelai adalah bila cocok bagi tanaman jagung. Tanaman kedelai dapat tumbuh dan berproduksi dengan baik di dataran rendah sampai ketinggian 900 meter di atas permukaan laut. Meskipun demikian telah banyak dari varietas kedelai dalam negeri ataupun introduksi yang dapat beradaptasi dengan baik di dataran tinggi (pegunungan) \pm 1.200 meter di atas permukaan laut (Rukmana, 1996). Pertumbuhan tanaman kedelai pada musim kemarau dengan suhu udara berkisar 20 30 OC dianggap lebih optimal dengan kualitas biji yang lebih baik dengan panjang penyinaran umumnya berkisar 11 - 12 jam/hari dan kelembapan udara yang optimal berkisar 75-90\% (Adisarwanto, 2014).

Iklim yang paling cocok untuk tumbuh dan berproduksi kedelai dengan baik adalah daerah-daerah yang mempunyai suhu antara 25 - 27 0C, kelembaban udara(RH) rata-rata $65 \%$, dan curah hujan antara 100 - $200 \mathrm{~mm} /$ bulan (Rukmana, 1996). Tanaman kedelai biasanya akan tumbuh baik pada ketinggian tidak lebih dari $500 \mathrm{~m}$ $\mathrm{dpl}$, bergantung varietasnya. Varietas berbiji kecil sangat cocok ditanam pada lahan dengan ketinggian 0,5 - $300 \mathrm{~m}$ dpl, sedangkan varietas kedelai berbiji besar cocok ditanam pada lahan dengan ketinggian 300 - 500 m dpl (Septiatin, 2012).

Air diperlukan tumbuhan untuk memenuhi kebutuhan biologis, antara lain untuk memenuhi transpirasi dalam proses asimilasi untuk pembentukan karbohidrat, serta untuk pengangkut hasil - hasil fotosintesis ke seluruh jaringan tumbuhan. Air merupakan bagian penyusun tubuh tumbuhan. Air tanah berfungsi sebagai pelarut unsur hara dan membawa unsur hara kepermukaan akar tumbuhan, di dalam jaringan tumbuhan air juga yang berperan mengangkut unsur hara yang diserap akar ke seluruh tubuh tumbuhan (Hakim dkk., 1986).

Tumbuhan dapat mengambil sejumlah air yang banyak dan teratur melalui pergerakan kapiler air tanah ke perakaran dan pertumbuhan akar ke arah tanah yang lembab. Pergerakan kapiler mengabsorpsi air dari suatu titik ke dalam tanah. Air di sekitar akan tertarik ke daerah absorpsi sedangkan perpanjangan akar sangat cepat dan terjadi kontak terhadap partikel tanah sehingga dapat memenuhi kebutuhan air bagi tumbuhan yang tumbuh pada keadaan air optimum (Hakim dkk., 1986).

Ketersediaan air tanah bagi pertumbuhan tanaman ditentukan oleh faktor iklim, tanaman, dan akar tanah, diantara sifat sifat tanah yang berpengaruh adalah daya hisap metrik dan osmotik kedaan tanah dan pelapisan tanah (Hakim dkk., 1986). Keadaan alamiah yang memenuhi persyaratan untuk pertumbuhan optimal jarang kita jumpai di lapangan, maka di dalam bertanam kedelai pengaturan air sangat perlu perhatian (Suprapto, 1999). Pengairan yang tepat akan memberikan produksi tanaman meningkatkan. Setyati (1991) menyebutkan bahwa jumlah air yang diberikan sebaiknya teratur sehingga kelebihan air tidak terlalu besar. Pada umumnya tanaman membutuhkan air yang banyak pada fase vegetatif. Hal ini ditegaskan Adisarwanto (2014) bahwa stadia tumbuh kedelai yang memerlukan curah air yang banyak atau kelembaban tanah yang cukup tinggi adalah pada stadia awal vegetatif (perkecambahan), stadia berbunga, serta stadia pembentukan atau pengisian polong. Namun, perlu diperhatikan bahwa curah hujan yang tinggi dapat menyebabkan polong busuk akibat kelembaban udara yang 
sangat rendah dan membuat kualitas biji kedelai yang dihasilkan menurun.

Air tersedia (air yang diserap tanaman) adalah air yang tertahan tanah pada kondisi kapasitas lapang hingga koefisien layu. Namun, mendekati koefisien layu tingkat ketersediannya semakin rendah, oleh karena itu untuk menjamin tercukupinya kebutuhan tanaman, suplai air harus diberikan apabila 50 - 58\% air tesedia ini telah habis terpakai (Utomo dan Islami, 1991).

Air merupakan komponen penting bagi berlangsungnya berbagai proses fisiologi seperti serapan hara, fotosintesis dan reaksi biokimia sehingga penurunan absorbsi air mengakibatkan hambatan pertumbuhan dan penurunan hasil. Menurut Gardner dkk (1989 dalam Parwati 2007), air yang merupakan penyusun utama jaringan tanaman berperan sebagai pelarut dan medium bagi reaksi metabolisme sel, medium untuk transpor zat terlarut, medium yang memberikan turgor pada sel tanaman, bahan baku untuk fotosintesis, proses hidrolisis dan reaksi kimia lain, serta evaporasi air untuk mendinginkan permukaan tanaman. Mengingat peran pentingnya air maka tanaman memerlukan sumber air yang tetap untuk pertumbuhan dan perkembangannya. Air seringkali membatasi pertumbuhan dan perkembangan tanaman budidaya. Respons tumbuhan terhadap kekurangan air dapat dilihat dari aktivitas metabolisme, morfologi, pertumbuhan dan produktivitas.

Proses fotosintesis membutuhkan air sebagai bahan baku dalam pembentukan fotosintat, khususnya karbohidrat, dimana $\mathrm{CO} 2$ + $\mathrm{H} 2 \mathrm{O}$ dengan bantuan cahaya akan membentuk $\mathrm{C} 6 \mathrm{H} 1206 . \quad$ Air terutama dibutuhkan pada fase cahaya sebagai sumber elektron untuk membentuk energi kimia dalam bentuk NADPH2 dan ATP. Energi kimia tersebut akan digunakan untuk mereduksi CO dalam fase gelap untuk menghasilkan $\mathrm{C} 6 \mathrm{H} 12 \mathrm{O} 6$ + 02. Jika tanaman mengalami cekaman air, maka laju fotosintesis terus menurun karena tidak mampu membentuk NADPH2 dan ATP yang cukup untuk memenuhi kebutuhan energi dalam mereduksi CO (Sarawa, 2012).

Dampak kekurangan air akan mempengaruhi turgor sel sehingga akan mengurangi pengembangan sel, sintesis protein, dan sintesis dinding sel. Pengaruh kekurangan air selama tingkat vegetatif adalah perkembangan daun yang ukurannya lebih kecil dapat mengurangi penyerapan cahaya. Kekurangan air juga mengurangi sintesis klorofil dan mengurangi aktivitas beberapa enzim (misalnya nitrat reduktase). Kekurangan air justru meningkatkan aktivitas enzim-enzim hidrolisis, seperti amilase (Gardner dkk,1989 dalam Parwati 2007).

Gardner dkk. (1989 dalam Parwati 2007) menjelaskan, fungsi air bagi tanaman yaitu:(1) sebagai senyawa utama pembentuk protoplasma, (2) sebagai senyawa pelarut bagi masuknya mineralmineral dari larutan tanah ke tanaman dan sebagai pelarut mineral nutrisi yang akan diangkut dari satu bagian sel ke bagian sel lain, (3) sebagai media terjadinya reaksireaksi metabolik, (4) sebagai reaktan pada sejumlah reaksi metabolisme seperti siklus asam trikarboksilat, (5) sebagai penghasil hidrogen pada proses fotosintesis, (6) menjaga turgiditas sel dan berperan sebagai tenaga mekanik dalam pembesaran sel, (7) mengatur mekanisme gerakan tanaman seperti membuka dan menutupnya stomata, membuka dan menutupnya bunga serta melipatnya daun-daun tanaman tertentu, (8) berperan dalam perpanjangan sel, dan (9) sebagai bahan metabolisme dan produk akhir respirasi serta (10) digunakan dalam proses respirasi

Kedelai termasuk tanaman yang tidak tahan terhadap kekeringan. Oleh karena itu, air sangat diperlukan sejak awal pertumbuhan sampai pada masa polong berisi. Jika pada fase pertumbuhan vegetatif kedelai mengalami kekeringan, pertumbuhan kedelai menjadi kerdil. Demikian pula kekeringan pada saat kedelaiberbunga atau polong mulai berisi akan mengakibatkan gagal panen, karena kekeringan, tanaman menjadi layu, pertumbuhan terhambat dan apabila tidak segera memperoleh air, tanaman akan menjadi mati (AAK, 2000).

Hasil penelitian Suhartono dkk. (2008) membuktikan bahwa interval penyiraman tanaman kedelai 1 liter per hari, 1 liter per 2 hari, dan 1 liter per 3 hari. menunjukkan perlakuan interval penyiraman memberikan pengaruh nyata terhadap tinggi tanaman dengan perlakuan 1 liter per 2 hari menghasilkan tanaman yang tertinggi. Lebih lanjut Noor dan Arintadisastra (2012) melaporkan bahwa pemberian air pada tanaman kedelai mampu meningkatkan produksi kedelai sebanyak 1 - 2 ton/ha

Menurut Sutedjo (2008), pupuk dalam arti luas termasuk semua bahan yang ditambahkan ke dalam tanah untuk menyediakan unsur yang esensial bagi pertumbuhan tanaman. Berdasarkan jumlah 
yang diperlukan tanaman, unsur hara menjadi dua golongan, yakni: unsur hara makro dan unsur hara mikro. Unsur hara makro diperlukan tanaman dan terdapat dalam jumlah lebih besar dibandingkan dengan unsur hara mikro. Walaupun kadar unsur hara berbeda, namun setiap jenis tanaman umumnya memiliki urutan berdasarnya kadar - kadarnya, yakni: $\mathrm{C}, \mathrm{H}$, $\mathrm{O}, \mathrm{N}, \mathrm{P}, \mathrm{K}, \mathrm{S}, \mathrm{Ca}, \mathrm{Mg}, \mathrm{Si}, \mathrm{Na}, \mathrm{Fe}, \mathrm{Mn}, \mathrm{Cu}$, $\mathrm{Zn}, \mathrm{Mo}$, dan $\mathrm{B}$. Nitrogen bersamasama $\mathrm{P}$ dan $\mathrm{K}$ merupakan unsur hara esensial primer, dan merupakan unsur yang paling sering mejadi faktor pembatas pertumbuhan tanaman (Munawar, 2011).

Pupuk sudah lama dikenal oleh para petani baik macam maupun penggunaannya terutama padi sawah, akan tetapi masih jarang petani kita menggunakan pupukdalam usaha bertanam dalam kacangkacangan. Pada umumnya mereka bertanam kedelai hanya dengan menyebar atau menugalkan benih setelah panen padi, tanpa dibarengi dengan pengairan, penyiangan, pemupukan dan pemakain insektisida (Suprapto, 1999). Kedelai menunjukkan respons terhadap pemupukan, terutama pada tanah yang miskin akan hara tanaman. Banyak pustaka yang mengatakan bahwa kedelai menghendaki persyaratan tingkat keasamaan yang netral untuk pertumbuhannya (Suprapto, 1999).

Aluminium bukan merupakan unsur esensial bagi pertumbuhan tanaman. Saat kelarutan Al meningkat seiring dengan turunnya $\mathrm{pH}$ hingga dibawah 5, unsur ini menjadi penting untuk diperhatikan karena menjadi toksik bagi tanaman. Bentukbentuk $\mathrm{Al}$ di dalam tanah dapat berupa ion trivalen yaitu $\mathrm{Al}\left(\mathrm{H}_{2} \mathrm{O}_{6}\right)^{3+}$ atau $\mathrm{Al}^{3+}$, bentuk hidroksida seperti $\mathrm{Al}(\mathrm{OH})_{2}{ }^{+}, \mathrm{Al}(\mathrm{OH})^{2+}$, $\mathrm{Al}(\mathrm{OH})_{3}, \mathrm{AL}(\mathrm{OH})_{4}^{-}$atau berasosiasi dengan berbagai senyawa organik dan anorganik seperti $\mathrm{PO}_{4}^{-3}, \mathrm{SO}_{4}{ }^{-2}$, asam-asam organik, protein dan lipid (Delhaize dan Ryan 1995). $\mathrm{Al}^{3+}$ merupakan bentuk yang paling toksik dan mendominasi di lahan asam dengan $\mathrm{pH}$ dibawah 4.5 (Matsumoto 2000).

Gejala keracunan Al tidak mudah diidentifikasi. Pada beberapa tanaman gejala keracunan Al mirip dengan defisiensi fosfor, yaitu pertumbuhan terhambat, tanaman kerdil, kematangan terhambat, urat-urat daun dan batang menjadi ungu, serta ujung daun berwarna kuning dan mati.
Namun terkadang keracunan Al mirip dengan defisiensi $\mathrm{Ca}$, yaitu keriput atau menggulungnya daun muda. Gejala keracunan Al yang paling mudah dilihat adalah penghambatan pertumbuhan akar. Penghambatan pertumbuhan akar telah banyak dilaporkan seperti pada padi (Nasution dan Suhartini1991), kedelai (Soepandi et al. 2000) dan gandum (Delhaiz dan Ryan 1995).

Aluminium terlarut bereaksi dengan dinding dan membran sel akar serta membatasi perluasan dinding sel sehingga menghentikan pemanjangan akar. Terhentinya pemanjangan akar merupakan ciri utama dari toksisitas Al. Jaringan akar merupakan bagian pertama dari tanaman yang mengalami keracunan $\mathrm{Al}$, terutama diujung akar sehingga mengalami pemendekan dan penebalan. Akar menjadi berwarna kecoklatan terutama pada akar utama serta terjadi pertumbuhan akar lateral yang gemuk dan pendek dengan percabangan yang tidak baik (Ryan et al. 1993).

Terdapat perbedaan tanggapan genotipe kedelai terhadap cekaman Al. Pada galur atau varietas peka terjadi penurunan produksi mencapai $50 \%$, sedangkan pada galur toleran hanya terjadi penurunan sekitar $10 \%$ (Board dan Cadwell 1991). Kedelai membutuhkan pengapuran jika ditanam pada tanah dengan kejenuhan Al lebih dari 35\% (Saleh dan Sumarno 1993). Ismunadji dan Mahmud (1993) melaporkan bahwa kedelai masih dapat tumbuh sampai kejenuhan $\mathrm{Al}$ 40\%. Ismunadji dan Mahmud (1993) juga menambahkan bahwa kejenuhan Al yang tinggi dapat mengurangi jumlah buku, tinggi tanaman, luas daun, pembentukan polong serta produksi kedelai.

Mekanisme toleransi tanaman terhadap keracunan Al sangat beragam. Taylor (1991) mengelompokkan mekanisme toleransi tersebut menjadi (1) mekanisme eksklusi, yaitu mekanisme yang berusaha menghambat Al masuk ke dalam sel tanaman dan (2) mekanisme inklusi yaitu suatu mekanisme yang memungkinkan tanaman melanjutkan proses tumbuhnya meskipun Al sudah masuk ke dalam sel tanaman.

Mekanisme eksklusi adalah imobilisasi Al di dinding sel dengan permeabilitas membran yang selektif, peningkatan $\mathrm{pH}$ rizosfer atau apoplas, eksudasi ligan 
pengkelat, eksudasi fosfat dan efluks Al (Taylor 1991). Plasma membran dapat dianggap sebagai penghalang penyerapan Al secara selektif. Duncan dan Baligar (1990) menyatakan bahwa perbedaan permeabilitas membran terhadap Al merupakan salah satu mekanisme toleran terhadap Al. Kemampuan apoplas sel akar menjerap Al juga dianggap sebagai salah satu mekanisme ketenggangan terhadap Al. Semakin kecil kemampuan akar untuk menjerap Al berarti tanaman semakin peka terhadap Al (Duncan dan Baligar 1990).

Marschner (1995) menyatakan bahwa tanaman yang toleran terhadap Al akan meningkatkan $\mathrm{pH}$ pada daerah perakaran sehingga menurunkan kelarutan dan keracunan aluminium. Tanaman toleran dapat menghambat Al masuk ke simplas jika ligan pengkelat (asam organik) dihasilkan,dengan membentuk kompleks Al yang kurang beracun. Ma et al. (2000) menyatakan toleransi kedelai terhadap Al berkaitan dengan kemampuan tanaman untuk mengeksudasi asam organik.

Mekanisme toleransi Al inklusi meliputi pengkelatan di sitosol, kompartemensasi di vakuola, dan adanya protein pengikat Al (Taylor 1991). Matsumoto (1991) menyimpulkan dari hasil penelitian pada membran mikrosomal akar barley bahwa aktivitas transpor $\mathrm{H}^{+}$tonoplas memegang peranan penting dalam pertukaran proton dengan Al yang dikompartementasi di vakuola.

Cekaman kekeringan merupakan istilah untuk menyatakan bahwa tanaman mengalami kekurangan air akibat keterbatasan air dari lingkungannya. Kekeringan disebabkan oleh dua hal yaitu : 1) kekurangan suplai air di daerah perakaran dan 2) permintaan air yang berlebihan oleh daun dimana laju evapotranspirasi melebihi laju absorbsi air oleh akar tanaman, walaupun keadaan air tanah cukup. Kekeringan adalah faktor pembatas penting pada pertumbuhan dan perkembangan tanaman. Fungsi air sangat penting yaitu sebagai pelarut dan media untuk reaksi kimia dan media untuk transpor, zat terlarut organik dan anorganik, media pemberi turgor pada sel tanaman, hidrasi dan netralisasi muatan pada molekul-molekul koloid, bahan baku fotosintesis, proses hidolisis, dan reaksi-reaksi kimia lainnya dalam tumbuhan serta transpirasi untuk mendinginkan permukaan tanaman (Gardner et al. 1991).

Setiap tumbuhan memiliki mekanisme yang berbeda dalam menanggapi kondisi lingkungan yang tidak optimal. Menurut Sheriff dan Muchow (1992) terdapat tiga mekanisme yang digunakan oleh tanaman untuk brtahan selama periode ketersediaan air rendah : 1) menghindari kekurangan air lingkungan, biasanya terjadi pada tanaman semusim dengan siklus hidup pendek. Tanaman akan berkecambah dan tumbuh menjadi tanaman dewasa, kemudian menghasilkan biji sebelum potensial air menurun; 2) menghindari kekurangan air jaringan, tanaman akan menutup stomata untuk mengurangi kehilangan air ketika potensial air -1.0 sampai -2.5 Mpa; 3) tolerator potensial air rendah, yaitu mampu mempertahankan stomata tetap terbuka sebagian dan melanjutkan fotosintesis meskipun potensial air menurun ( -10 sampai -12 Mpa).

Menurut Pugnaire et al. (1999), berdasarkan responnya terhadap kekeringan, tanaman dapat diklasifikasikan menjadi 1) tanaman yang menghindari kekeringan (drought avoiders) dan 2) tanaman yang mentoleransi kekeringan (drought tolerator). Tanaman yang menghindari kekeringan membatasi aktivitasnya pada periode air tersedia atau akuisisi air maksimum antara lain dengan meningkatkan jumlah akar dan memodifikasi struktur dan posisi daun. Tanaman yang mentoleransi kekeringan mencakup penundaan dehidrasi atau mentoleransi dehidrasi. Penundaan dehidrasi mencakup peningkatan sensitivitas stomata dan perbedaan jalur fotosintesis, sedangkan toleransi dehidrasi mencakup penyesuaian osmotik.

Potensial air $\left(\Psi_{\mathrm{W}}\right)$ merupakan sistem yang menggambarkan tingkah laku air dan pergerakan air dalam tanah dan tubuh tanaman yang didasarkan atas hubungan energi potensial dengan satuan ukur bar atau pascal (pa). Potensial air tanah berubungan langsung dengan kapasitas lapang dan titik layu permanen. Energi potensial air tanah ( $\Psi$ tanah) pada kapasitas lapang yaitu -0.1 sampai -0.3 bar, dan $\Psi$ tanah pada titik layu permanen berkisar 15 sampai -50 bar. Kapasitas lapang adalah air yang tetap tersimpan dalam tanah yang tidak mengalir ke bawah karena gaya gravitasi, dan titik layu permanen layu permanen yaitu kondisi air tercekam sehingga tanaman akan layu dan tidak akan segar kembali (Gardner et al. 1991).

Cekaman kekeringan berpengaruh terhadap fisiologi, morfologi dan biokimia tanaman. Salisbury dan Ross (1995) melaporkan bahwa pada kondisi potensial air 
lebih negatif mengakibatkan pembentukan klorofil terhambat, terjadi penutupan stomata, penurunan aktivitas enzim seperti nitrat reduktase, fenilalanin amonialinase, dan beberapa enzim lainnya. Sebaliknya aktivitas enzim a-amilase dan ribonuklease meningkat dalam perombakan pati dan bahan lain untuk membuat potensial osmotik lebih negatif sehingga tanaman tahan kekeringan.

Kondisi tercekam kekeringan juga mempengaruhi biokimia sel tanaman, salah satu yang dipengaruhinya adalah konsentrasi ABA (Absisic Acid). Pada kondisi potensial air rendah, konsentrasi ABA pada jaringan daun dan dalam jaringan lain meningkat sehingga terjadi penutupan stomata sehingga transpirasi dapat dicegah. Selain itu ABA berperan dalam penghambatan pertumbuhan pucuk daun dan memicu pertumbuhan akar (Wattimena 1988). Dengan demikian, laju transpirasi dapat dicegah sebaliknya penyerapan air meningkat. Selama terjadi kekurangan air, ABA dibebaskan dari kloroplas ke dalam selsel epidermis, kemudian kinerja proton dihambat yang aktivitasnya tergantung dari ATP (Adenosin tripospat) yang berada di membran plasma sel penjaga. Kinerja dari pompa proton yaitu mengangkut proton keluar dari sel penjaga sehingga menyebabkan terjadinya aliran masuk yang sangat cepat dan penimbunan ion $\mathrm{K}^{+}$, kemudian terjadi penyerapan air secara osmotik dan terjadi pembukaan stomata.

Respon fisiologi dan biokimia yang ditimbulkan oleh cekaman kekeringan akan berdampak terhadap karakter atau respon morfologi suatu tanaman, tetapi dengan respon yang berbeda-beda. Syafi (2008) menemukan bahwa cekaman air berpengaruh terhadap respon morfologi dan fisiologi jarak pagar pada peubah tinggi tanaman, luas daun, ketebalan daun, jumlah stomata terbuka, bobot kering pucuk, bobot kering akar, panjang akar, volume akar, kadar air daun, kandungan klorofil dan karbon serta asimilasi.

Perkembangan luas daun selama pertumbuhan vegetatif merupakan waktu yang sangat sensitif terhadap kekurangan air. Peningkatan turgor dalam proses pembelahan sel membutuhkan air yang cukup. Oleh karena itu kekurangan air pada waktu ini dapat menyebabkan menurunnya luas daun (Granier dan Tardieu 1999).
Kekeringan menyebabkan penurunan bobot kering tajuk, diameter batang, jumlah cabang produktif, jumlah polong berisi, jumlah biji per tanaman dan bobot kering biji (Hapsoh et al. 2004), menurunkan laju fotosintesis dan indeks luas daun tanaman (Sloane et al. 1990), menyebabkan tanaman memendek, menekan perkembangan akar dan tajuk kedelai, mempercepat pembungaan dan umur panen (Jusuf et al. 1993). Soepandi et al. (1997) juga menyatakan bahwa cekaman kekeringan dapat mengurangi jumlah polong berisi sehingga menurunkan produksi kedelai dan dapat menyebabkan jumlah biji per polong menurun akibat terjadinya gugur bunga dan polong pada saat fase pembungaan dan pembesaran polong (Liu et al. 2003), sedangkan kekeringan pada fase akhir pengisian polong akan mengurangi kepadatan biji (Liu et al. 2004). De Souza et al.(1997) melaporkan bahwa cekaman kekeringan menurunkan jumlah biji per tanaman kedelai.

\section{METODOLOGI PENELITIAN}

\subsection{Tempat dan Waktu Percobaan}

Penelitian ini telah dilaksanakan di Rumah Kaca, Kebun Percobaan Cikabayan, University Farm, IPB Darmaga Bogor, dari bulan Juli sampai November 2011. Analisis fisik dan kimia tanah dilakukan di Balai Besar Penelitian Tanah, Bogor.

\subsection{Alat dan Bahan}

Alat yang digunakan antara lain adalah rhizotrone, cangkul, ayakan, timbangan, mistar, gembor, plastik transparansi, pinboard, thermometer. Bahan yang digunakan antara lain adalah tanah Ultisol Tenjo (Kabupaten Bogor Barat) yang memiliki $\mathrm{pH} 4.6$ dan Aldd 5.88 me $/ 100 \mathrm{~g}$, polybag ukuran $35 \mathrm{~cm} \times 45 \mathrm{~cm}$, kedelai galur SP 30-4 (Slamet//Pangrango), galur PG 57-1 (Pangrango//Godek), varietas Anjasmoro dan varietas Tanggamus, pupuk SP18, KCl, kapur (CaCO3), Rhizobium serta Marshall

\subsection{Metode Penelitian}

Percobaan menggunakan Rancangan Acak Lengkap dengan 3 faktor. Faktor I adalah genotipe kedelai yang terdiri atas 4 genotipe yaitu SP 30-4 (G1), Anjasmoro (G2), PG 57-1 (G3) dan Tanggamus (G4). 
Faktor II adalah interval penyiraman yang terdiri atas : 2 hari (K1), 6 hari (K2), dan 10 hari (K3). Faktor III adalah netralisasi Al dengan pengapuran yang terdiri atas : $0 \%$ Aldd (N1) dan $100 \%$ Aldd (N2)

\subsection{Pelaksanaan Penelitian \\ 3.4.1. Persiapan Media Tanam}

Tanah dijemur selama seminggu dan dihaluskan dengan menghancurkan bongkahan tanah untuk memudahkan pengayakan. Setelah diayak dan diaduk rata diambil sampel untuk kebutuhan analisa tanah awal. Rhizotrone diisi dengan $7 \mathrm{~kg}$ tanah dan disusun berdasarkan denah percobaan

Kebutuhan kapur dihitung berdasarkan Aldd yang diketahui berdasarkan analisa tanah awal (Lampiran 3). Pengapuran dilakukan 2 minggu sebelum penanaman benih, dengan dosis 29.4 g $\mathrm{CaCO} 3 /$ polybag untuk perlakuan $100 \%$ Aldd. Selama masa inkubasi (2 minggu), media tanah yang telah dicampur rata dengan kapur disiram setiap hari dengan 1 liter air.

\subsubsection{Penanaman}

Benih kedelai ditanam dalam rhizotrone sebanyak 2 biji dan pada umur 1 minggu setelah tanam (MST) dijarangkan menjadi 1tanaman/rhizotrone. Pupuk dasar yang diberikan setara $400 \mathrm{~kg}$ SP18/ha dan $100 \mathrm{~kg} \mathrm{KCl} / \mathrm{ha}$ pada saat tanam. Sebelum ditanam benih diberi inokulant Rhizobium 5 $\mathrm{g} / \mathrm{kg}$ benih dan Marshall $15 \mathrm{~g} / \mathrm{kg}$ benih untuk mengendalikan lalat bibit.

\subsubsection{Penyiraman}

Pada awal penanaman sampai umur 2 MST, penyiraman dilakukan dengan menggunakan 1 liter air/hari. Perlakuan interval penyiraman dimulai 2 MST sampai panen dengan menambahkan 1 liter air untuk interval penyiraman 2 hari, 1.5 liter untuk interval penyiraman 6 hari dan 2 liter untuk interval penyiraman 10 hari. Jumlah air yang diberikan melebihi kapasitas lapang, dengan maksud agar air yang diberikan dapat secara merata membasahi media tanah di dalam rhizotrone sehingga mencapai kapasitas lapang setiap kali penyiraman.

Perhitungan air kapasitas lapang

\subsubsection{Pengamatan}

Pengamatan pada percobaan ini meliputi :

1. Umur berbunga dan fruitset
2. Panjang akar vertikal saat panen

3. Bobot kering bintil akar saat panen

\subsubsection{Prosedur Analisis Data}

Data yang diperoleh dianalisis dengan anova, bila terdapat pengaruh perlakuan dilanjutkan dengan uji lanjut Duncan Multiple Range Test (DMRT) pada taraf $5 \%$. Peubah tinggi tanaman dan jumlah daun dianalisis dengan metode faktorial in time. Korelasi antar peubah dilakukan dengan menggunakan metode korelasi Pearson.

\section{HASIL DAN PEMBAHASAN}

\subsection{Umur Berbunga}

Hasil pengujian menunjukkan respon tanaman kedelai terhadap cekaman Al berbeda antar genotipe (Tabel 6).Cekaman Al meningkatkan umur berbunga genotipe SP 30-4 dan Tanggamus. Pada peubah umur berbunga, kedua genotipe ini menunjukkan respon yang peka terhadap cekaman Al. Genotipe Anjasmoro dan PG 57-1 menunjukkan respon yang toleran terhadap cekaman Al karena umur berbunga kedua genotipe ini tidak menunjukkan perbedaan antara yang tercekam dan yang tidak tercekam Al.

Tabel 6 Respon umur berbunga genotipe tanaman kedelai terhadap cekaman Al

\begin{tabular}{ccc}
\hline \multirow{2}{*}{ Genotipe } & \multicolumn{2}{c}{ Umur berbunga (hari) } \\
\cline { 2 - 3 } & $\begin{array}{c}\text { Netralisasi Al } \\
(100 \% \text { Aldd) }\end{array}$ & $\begin{array}{c}\text { Netralisasi Al } \\
\text { (0\% Aldd) }\end{array}$ \\
\hline SP 30-4 & $41.1 \mathrm{bc}$ & $44.4 \mathrm{a}$ \\
Anjasmoro & $35.4 \mathrm{~d}$ & $34.3 \mathrm{~d}$ \\
PG 57-1 & $39.7 \mathrm{c}$ & $40.9 \mathrm{bc}$ \\
Tanggamus & $39.2 \mathrm{c}$ & $42.2 \mathrm{~b}$ \\
\hline
\end{tabular}

Keterangan : angka yang diikuti huruf yang sama tidak berbeda nyata pada uji DMRT taraf $5 \%$

Terlambatnya pembungaan SP $30-4$ dan Tanggamus pada kondisi ini disebabkan tingginya Al dalam media perakaran. Ion Al dapat menghambat pembungaan melalui penghambatan terhadap pertumbuhan akar, sehingga laju alokasi substrat ke bagian tajuk menjadi rendah (Hanum 2004).

\subsection{Panjang Akar}

Hasil pengujian menunjukkan bahwa interaksi antara perlakuan genotipe, cekaman kekeringan dan cekaman Al mempengaruhi panjang akar genotipe kedelai. Pada Gambar 2a dan 2b dapat dilihat bahwa cekaman Al tidak mempengaruhi panjang akar SP 30-4 dan Anjasmoro. Pada saat tercekam Al, panjang 
akar PG 57-1 lebih panjang pada interval penyiraman 10 hari dibandingkan interval penyiraman 2 hari. Pada interval penyiraman 6 hari, panjang akar Tanggamus lebih panjang saat tercekam Al dibandingkan tidak tercekam Al. Semua genotipe menunjukkan respon toleran pada peubah panjang akar, karena memiliki kemampuan memulihkan dan menekan pengaruh buruk dari Al sehingga fungsi akar tidak terganggu. Pertumbuhan akar yang tidak terganggu oleh keberadaan Al akan memiliki kemampuan untuk beradaptasi pada kondisi tercekam kekeringan.

Genotipe PG 57-1 memperlihatkan mekanisme avoidance terhadap kekeringan pada kondisi tercekam Al. Pada mekanisme ini tanaman mempunyai kemampuan untuk meningkatkan sistem perakaran. Mekanisme adaptasi dengan meningkatkan sistem perakaran adalah dengan menghambat pertumbuhan bagian atas karena sebagian besar karbohidrat ditranslokasikan untuk memproduksi akar lebih banyak. Hal ini diduga berhubungan dengan konsentrasi ABA yang meningkat dengan adanya kekeringan yang berperan dalam penghambatan pertumbuhan pucuk daun dan memicu pertumbuhan akar (Wattimena 1988). Hamim (1995) juga menemukan adanya peningkatan panjang akar pada kedelai yang ditanam pada kondisi kekeringan daripada kondisi cukup air.

Gambar 2b memperlihatkan bahwa pada kondisi tidak tercekam Al, panjang akar Anjasmoro tidak dipengaruhi oleh peningkatan interval penyiraman. Panjang akar genotipe SP 30-4 dan PG 57-1 menurun secara nyata pada kondisi interval penyiraman 10 hari, sedangkan panjang akar varietas Tanggamus tertekan pada interval penyiraman 6 hari dan 10 hari. Varietas Anjasmoro memperlihatkan respon toleran terhadap kekeringan karena peningkatan interval penyiraman tidak mempengaruhi panjang akarnya. Taiz dan Zeiger (2002) menjelaskan bahwa tanaman dapat bertahan terhadap cekaman kekeringan dengan membatasi perkembangan luas daun, perkembangan akar untuk mencapai daerah yang masih basah dan penutupan stomata untuk mengurangi transpirasi.

Namun demikian, kemampuan tanaman beradaptasi terhadap cekaman kekeringan tidak hanya ditentukan oleh panjang akar, tetapi juga ditentukan oleh jumlah akar per satuan luas. Jumlah, panjang dan kerapatan akar yang lebih besar akan membentuk rambut akar dalam jumlah yang lebih banyak, sehingga dapat meningkatkan luas bidang serap yang merupakan komponen paling efektif dalam absorbsi air (Gardner et al. 1991). Cruzz et al. (1992) juga menambahkan bahwa kemampuan akar untuk mengabsorbsi air sangat tergantung pada struktur dan anatomi akar sehingga akar yang panjang akan memiliki bidang serap yang lebih tinggi.

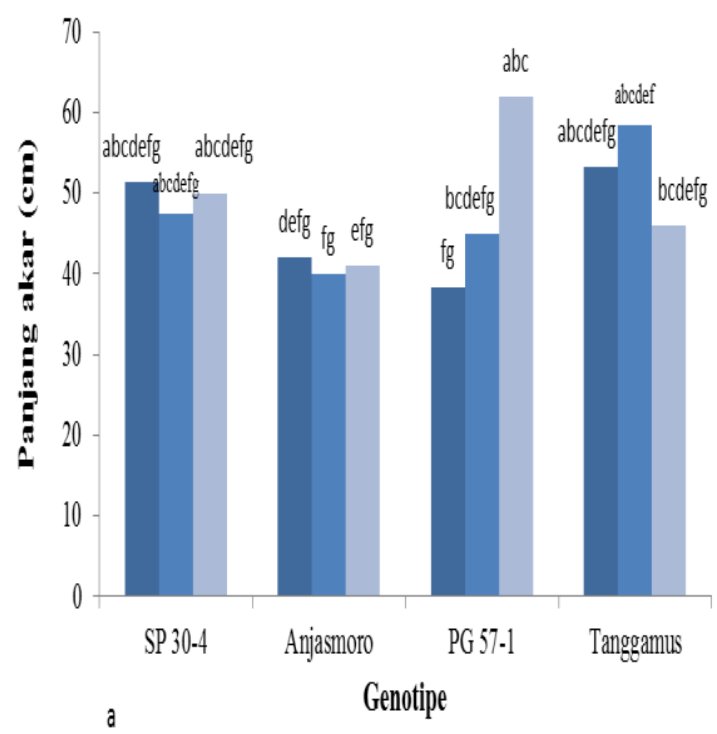

Keterangan : Penyiraman $\square$ hari Penyiraman 6 hari Penyiraman 10 hari Gambar Respon panjang akar genotipe kedelai terhadap cekaman kekeringan pada kondisi (a) tercekam Al dan (b) tidak tercekam Al

\subsection{Bobot Kering Akar}

Hasil pengujian menunjukkan bahwa interaksi cekaman kekeringan dan cekaman Al mempengaruhi bobot kering akar tanaman kedelai (Gambar 3), tetapi tidak dapat menjelaskan kaitannya dengan faktor genotipe karena interaksi antara perlakuan dengan genotipe tidak berbeda nyata pada peubah ini.Pada kondisi tidak tercekam Al, bobot kering akar belum terlihat tertekan pada interval penyiraman 6 hari, dan mulai tertekan pada interval penyiraman 10 hari. Pada interval penyiraman 10 hari, bobot 
kering akar tanaman yang tercekam Al maupun yang tidak Al memiliki nilai yang sama.

Berikatannya Al dengan perakaran menyebabkan penghambatan pembelahan dan perpanjangan sel akar (Matsumoto 1991) sehingga menghambat perpanjangan akar (Marshner 1992) yang secara tidak langsung akan menurunkan bobot kering akar. Hal ini sesuai dengan hasil penelitian Soepandi et al. (2000), bahwa cekaman Al menekan panjang akar dan bobot kering akar.

Pada kondisi tidak tercekam Al, bobot kering akar semakin menurun dengan semakin meningkatnya periode kekeringan. Kadar air media mempengaruhi kemampuan tanaman untuk membentuk akar. Pada percobaan ini, keempat genotipe tidak memperlihatkan perbedaan kemampuan untuk mempertahankan bobot kering akar pada kadar air media rendah. Bobot kering akar pada kadar air media rendah disebabkan bagian ujung akar yang berperan dalam zona pemanjangan tidak tumbuh dengan baik, begitu juga dengan rambut-rambut akar yang berperan dalam penyerapan air (Aini 2013).

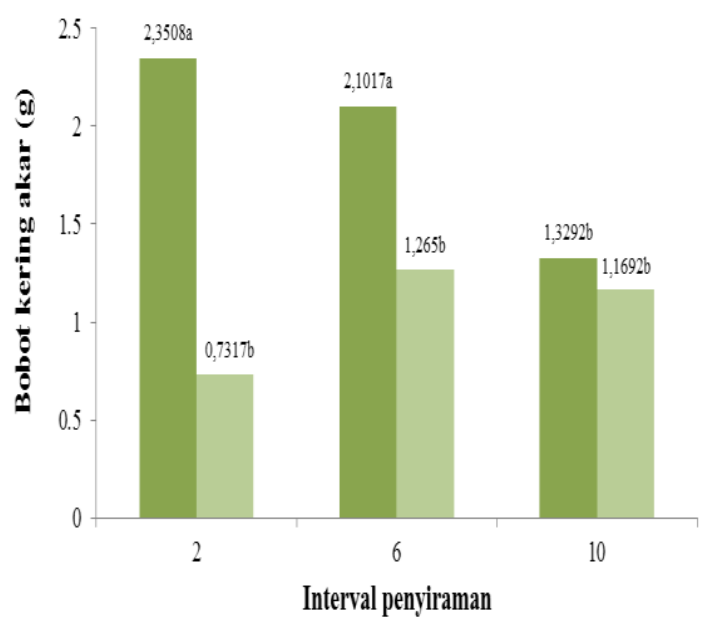

Keterangan : Netralisasi $100 \%$ Aldd Netralisasi 0\% Aldd Gambar Respon bobot kering akar tanaman kedelai terhadap interaksi cekaman Al dan kekeringan

\section{KESIMPULAN DAN SARAN \\ 5.1. Kesimpulan}

Semakin tinggi nilai peubah yang diamati, semakin tinggi jumlah polong yang dihasilkan. Hal ini juga terjadi pada peubah umur berbunga, panjang akar vertikal, bobot kering bintil akar
Pada umumnya peubah komponen hasil tanaman kedelai, lebih banyak dipengaruhi oleh cekaman kekeringan. Namun peubah umur berbunga hanya dipengaruhi oleh cekaman Al pada genotipe yang berbeda.

\subsection{Saran}

Perlu dilakukan penelitian lanjut untuk melihat hubungan antara daya pulih akar dengan pertumbuhan vegetatif dan pertumbuhan generatif dengan perlakuan yang lebih rinci

\section{DAFTAR PUSTAKA}

[1] AAK. 2000. Kedelai. Kanisius. Yogyakarta. Hal. 11-23.

[2] Adisarwanto. 2008. Budidaya Kedelai Tropika. Penebar Swadaya. Jakarta. Hal.7-14.

[3] Adisarwanto. 2014. Budidaya Kedelai Tropika. Penebar Swadaya. Jakarta. Hal.5-25.

[4] Gardner, F.P., Pearce R.B, dan Mitchell, R. L. 1989.Fisiologi Tanaman Budidaya. Diterjemahkan oleh Susilo, $\mathrm{H}$ dan Subiyanto., 1991. Penerbit Universitas Indonesia (UI Press). Jakarta.

[5] Hakim, Nurhajati., M. Yusuf Nyakpa, A.M. Lubis, Sutopo Ghani Nugroho,M.Amin Diha, Go Ban hong, dan Bailey. 1986. Dasar-Dasar IImu Tanah.Universitas Lampung press. Lampung. Hal. 65.

[6] Noor, I dan Arintadisastra Sumitro. 2012. Revolusi Pertanian dan Kearifan Lokal. Bandung.

[7] Sarawa, Nurmas Andi, dan Dasril Aj Muh. 2012. Pertumbuhan dan Produksi Tanaman Kedelai(Glycine max (L.)Merril) Yang Diberi Pupuk Guano Dan Mulsa Alang-Alang. Kendari. Jurnal Agroteknos.2(2) :97-105.

[8] Septiatin, A. 2012. Meningkatkan Produksi Kedelai di Lahan Kering, Sawah, dan Pasang Surut.CV. Yrama Widya. Bandung.

[9] Setyati. 1991. Pengantar Agronomi. Gramedia Pustaka Utama, Jakarta.

[10]Suhartono. R. A, Zm Zaed Sidqi, Khoiruddin. Ach. 2008. Pengaruh Interval Pemberian Air Terhadap Pertumbuhan dan Hasil Kedelai (Glycine $\max ($ L.)Merril). Pada Berbagai Jenis Tanah. Universitas Trunojoyo Madura(Unijoyo). 
[11] Suprapto, HS. 1999. Bertanam Kedelai, PT. Penebar Swadaya, Jakarta. Hal. 3541

[12] Sutedjo, MM. 2008.Pupuk dan Cara Pemupukan.Jakarta:Rinekacipta: Jakarta.

[13] Utomo dan Islami. 1991. Budidaya Pertanian Olah Tanah Konservasi. Makalah Jumpa Paket Teknlogi Pertanian. Bandar Lampung.

[14] Munawar, A. 2011. Kesuburan Tanah dan Nutrisi Tanaman. Institut Pertanian Bogor Press. Bogor. 